\section{B A Institute of \\ YK Business Administration \\ 光र \\ Karachi \\ Leadership and Ideas for Tomorrow}

Business Review

Volume 2 Issue 1 January - June 2007

$1-1-2007$

\title{
Investigating technicist-managerialism in the values endorsed in MBA programmes
}

Sara Khan

Institute of Business Administration, Karachi, Pakistan

Follow this and additional works at: https://ir.iba.edu.pk/businessreview

Part of the Curriculum and Social Inquiry Commons, and the Educational Leadership Commons

(c) (i)

This work is licensed under a Creative Commons Attribution 4.0 International License.

\section{Recommended Citation}

Khan, S. (2007). Investigating technicist-managerialism in the values endorsed in MBA programmes. Business Review, 2(1), 76-98. Retrieved from https://doi.org/10.54784/1990-6587.1114

This article is brought to you by iRepository for open access under the Creative Commons Attribution 4.0 License and is available at https://ir.iba.edu.pk/businessreview/vol2/iss1/7. For more information, please contact irepository@iba.edu.pk. 


\title{
ARTICLE
}

\section{Investigating Technicist-managerialism in the Values Endorsed in MBA Programmes}

\author{
Sara Khan \\ Institute of Business Administration, Karachi, Pakistan
}

\begin{abstract}
This article investigates the incidence of technicist-managerialism in two MBA programmes of Pakistan by inquiring into the values endorsed in them. Findings about values found in the two schools are presented in the form of quotes from interviews and excerpts from official publications of these two business schools. Consequences of such thinking are then discussed in the light of management literature.
\end{abstract}

\section{INTRODUCTION}

7 he MBA degree is among the most popular degrees in the world. Management 1 education was initially introduced in the North American business school of Wharton in 1881, followed by the schools in Harvard in 1908 and Stanford in 1925. Friga et al (2003) point out that internationally undergraduate business degrees have grown from $14 \%$ of all undergraduate degrees in 1971 to $19 \%$ in 1997 . For the Master of Business Administration (MBA), the figures are $11 \%$ and $23 \%$ respectively. Corporations and educational institutions spend a combined \$2.2 trillion on management education and training worldwide, with nearly $\$ 885$ billion in the United States alone. At present there are about 1500 business schools offering MBA courses over the globe (anonymous, 2005).

The MBA degree is among the most popular degrees in Pakistan. Many of the 114 HEC recognized institutes are pure business schools, while many others offer degrees in business administration. In April 2005 the HEC formulated a National Curriculum Revision Committee (NCRC) for Business Administration that revised in consultation with representatives of several public and private business schools the curricula for BBA (Hons.) and MBA programmes of the country. This is perhaps the biggest attempt at standardizing the MBA curriculum in the country. For example, the Committee has decided that the BBA (Hons.) degree will be extended to 4 years and the MBA to 2 years of full-time study in order to provide students a well-rounded education in the field of business administration. A list of subjects to be taught in each of the programmes has been drawn up, along with an approved list of text books for each. A majority of the text books are written by Western, particularly American authors. Those that are by Pakistani authors are usually, but not exclusively, for subjects that talk specifically about Pakistan and Islam, such as Pakistan Studies and Islamiyat ${ }^{l}$.

${ }^{1}$ www.hec.gov.pk 


\title{
2. TECHNICIST-MANAGERIALIST THINKING IN THE MBA CURRICULA: A REVIEW OF LITERATURE
}

\author{
Technicist-managerialist origins of the MBA degree:
}

According to one theory, management education originated in the military academy at West Point and the Pennsylvania Railroad to solve managerial problems from the point of view of managers. Hence it emphasized techniques and was strategic in nature. Moreover, concerns about the quality of business education in the early 1950s led to the commissioning of two influential reports, the Carnegie Report and the Ford Report, by the US government, which recommended changes to the business education curriculum. The American Assembly of Collegiate Schools for Business (AACSB) implemented the recommendations of these reports in 1961 by introducing 'standards' for business education masters courses, and in these standards the term 'MBA degree' was first used (Currie and Knights, 2003). A reason they had the word Administration, rather than Management in the title was because of the influence of civil or bureaucratic governments in school affairs and because MBAs were needed to run statistical operations in administration (Fox, 2001). Thus technical and managerial thinking, often codified into standards, became a paramount feature of the MBA degree. In the following paragraphs I explain this conception before moving on to how it is fostered in MBA programmes through their pedagogy and by catering to their stakeholders.

\section{Defining technicist-managerialist thinking}

Grey and Mitev (1995a: 74) define managerialist thinking as

treating management as a morally and politically neutral activity. Hence, management education becomes primarily concerned with the acquisition of techniques, regardless of the context of their application (also see Perriton, 2000, for further explanation of the concept).

In other words, such a discourse presents management as an 'unproblematic set of techniques and practices' (Grey and Mitev, 1995a : 76). Students too often imply an attitude to learning management as a set of techniques that should be 'useful', 'practical' and 'relevant to the real world.' Techniques here do not only refer to those used in mechanical accounting and operations management, but also include those employed in dealing with people and change management. Such a technicist label, say Grey and Mitev (1995a: 77), 'relates not only to the focus on techniques but also to the fact that the technicist approach is illuminated by commitment to instrumental rationality ${ }^{2}$.'

Since both the providers and seekers of management education concentrate on giving and acquiring a morally and politically neutral set of techniques and practices and

\footnotetext{
${ }^{2}$ By instrumental rationality, the authors mean 'a rationality which is concerned only with the adoption of the most appropriate means to achieve a given end, as opposed to reflection upon the rationality and desirability of ends themselves'(Grey and Mitev, 1995a: 88).
} 
because such a thinking perceives management as a technical activity, throughout this article I refer to this kind of thinking as technicist-managerialist.

\section{Fostering technicist-managerialist thinking through pedagogy:}

This section illustrates how various elements in the current MBA pedagogy, such as courses, concepts, teaching methodology, and the examination system foster a technicistmanagerialist mode of thinking that neglects emotional and ethical values and concerns.

Many management scholars, such as Alvesson and Willmott (1996), Grey, Knights and Willmott (1996), and Kallinikos (1996) for example, assert that positivism is the dominant ideology in management circles of today. They believe that courses such as economics and psychology usually give students numerical and linear cause-effect models, while marketing and accounting appear deceptively simple. Their concern is profitability. Marketing creates stereotypes and appeals to newness. Computing restricts the moral element in decision-making, seeming to further subordination, rather than emancipation. Gosling and Mintzberg (2004) observe that the subject matter too is divided into sharp categories, not fully in resonance with people's experiences, nor including a study of ethics. Spivak (1993) thus calls business schools 'teaching machines' in their being highly influential in production and dissemination of a certain type of knowledge.

Huczynski (1993), Fineman and Gabriel (1994) and Birnbaum (2000) criticize popular concepts and models, such as TQM (Total Quality Management), Excellence, MBO (Management by Objectives) BCG (Boston Consulting Group - a matrix on business strategy), and BPR (Business Process Reengineering) and best practices, taught in the MBA syllabi, for giving an account of a reality that appears easily manageable. Fineman and Gabriel (1999) see the problem of science-like predictability reflected in the definitions and textbook covers as well. 'Definitions semantically fix concepts to what are presumed to be facts in the real world' (p. 381), while Organization Studies textbooks usually have covers decorated with geometric patterns, stylized human figures and jigsaw puzzles - features 'concordant with an organizational world that is predictable, and a philosophy of science that stresses regularity and laws' (p. 380).

Thus Kallinikos (1996) and Thomas and Anthony (1996) observe that, based on utilitarian thinking and, I add, an understanding of reality that is predictable, models in MBA programmes not only neglect deeper understanding of business issues but also disregard or give very little importance to human rights. Lataif et al (1992), Boyatzis et al (1995), Cavanaugh and Prasad (1996) and Clegg and Ross-Smith (2003) conclude that management education is preoccupied with the objective, rational and masculine part of management and marginalizes emotional and ethical concerns.

In addition to sidelining emotional concerns, technicist-managerialist thinking, as some of the above authors have commented, also neglects ethical concerns. Mitroff and Denton (1999) and Roy and Roy (2004) express that in management circles, in comparison to core business concepts, spirituality and ethics are considered airy 
concepts, above the realities of everyday practice. Hence students find them irrelevant to business life (Zych, 1999; Baetz and Sharp, 2004). McDonald (2004:372) also lists other reasons that are commonly presented against the teaching of ethics in business education:

- One can not teach moral standards

- Ethics are not part of the domain of business studies

- Ethics do not have analytical foundation of the kind other business subjects have. As such the topic lacks credibility

- If ethics courses are taught, it is primarily for appearance

- Students are not able to transfer ethical skills to work life

Among practical reasons, Baetz and Sharp (2004) observed in their research that some of the reasons why teaching of ethics is a challenge in management studies is curriculum constraints, lack of subject material, and lack of teachers' ability to deal with the subject. In their study of textbooks on various business subjects, they found few textbooks acknowledging the existence of ethical theory; those that dealt with the topic covered it in a variety of different ways, with little consistency in these varied approaches. This makes not only the study of the topic difficult but also hampers training of teachers in the subject.

Regarding teaching methodology, case studies - which are frequently used in MBA programmes - reinforce technicist thinking, according to Ehrensal (2002). Coming prepared with answers or solved by the teacher's own understanding of the problem, they give students the idea that they can solve any company's problems after just two hours of desk work, using the theories and analytical skills they have learnt.

In addition, the tightly packed MBA routine creates pressure, not permitting much reflection of the kind that not only means musing, but also wondering, analyzing, and struggling, say Gosling and Mintzberg (2004). Lists, so commonly found in management texts, foster 'routinized learning' rather than argument, providing a 'short-cut to understanding' (Fineman and Gabriel, 1999: 383). Moreover, believing themselves to be customers of business knowledge, business students expect knowledge to come to them in 'a pre-digested and immediately usable form' which the teacher happily imposes on them (Roberts, 1996:56; Currie and Knights, 2000), for example through lectures and handouts, I think. Moreover, according to Currie and Knights (2000:100), use of modern technology, such as OHPs (overhead projectors), Power Point and videos, in teaching further strengthens the technist thinking by 'remove[ing] the dynamic quality of teaching and thus make[ing] the experience of students more formal and distant.'

Test scores and grades, that are only one measure of student performance (Gosling and Mintzberg, 2004) and MBA ranking lists and accreditations (anonymous, 2005) that are only one measure of school performance, in my opinion, further reinforce the technicist calculative mentality. By encouraging students to compete for higher grades, opt for prestigious schools, pay attention to market rankings and calculate return on investment (ROI) when selecting programmes of study, as a Business report 
2.0 (2005) recommends, such measures, I believe, can reduce the due importance of other criteria of learning and selection, such as the opportunity to benefit from professors and colleagues, to develop a spirit of inquiry, and to select courses of interest.

Fostering technicist-managerialist thinking through catering to market requirements:

In addition to its pedagogy, another way I see MBA programmes technicist- managerialist in their outlook is their consideration of education as a product for the market of students and employers, with both providers and seekers of education seeing it as a commercial exchange, defined in terms of specific, definitive requirements. Evidence of this can be found in various aspects, from teaching to distribution, of MBA education. For one, metaphors, such as quality assurance, benchmarks, exporting education or marketing syllabi, standardizing educational products, and students as customers are increasingly heard in business academia and market. Secondly, league tables, targetsetting (Cope and I'Anson, 2003), calculating return on investment (ROI), and rankings (Business 2.0, 2005) promote such conceptions. Students' evaluations of teachers further add to the 'teacher as producer' and 'student as consumer' concept (Grey and Mitev, 1995a). Studies have demonstrated that recruiters too do not always give much importance to behavioural coursework in education. Rynes et al's (2003) study, for example, showed that while evaluating resumes, employers gave same employability rating to students who took both functional and behavioural coursework as to those who studied only functional subjects, although $78 \%$ of them had indicated in an earlier study that they preferred graduates who supplemented behavioural coursework with functional expertise. Such findings send confusing signals to students and educators who therefore do not consider behavioural coursework as important as functional. Burke et al (2003) had also written that many students find OB (Organizational Behaviour) matters, which deal with people management, 'common sensical, unimportant, irrelevant and of little use to them.'

Auken et al (2005:44) state industry's influence on MBA programmes in these words

Most MBA programs are indeed influenced by their stakeholders. More and more, the student is being treated as a customer, and student and alumni satisfaction have become key metrics along with employer and recruiter satisfaction. At the same time, the student is also a product. Therefore, it may be that narrowing of core curricula in favor of marketable skill building has gone too far.

Pring (1998) also believes that development of the intellect as a goal of education is becoming difficult because of economic reasons: research agendas are set by economic, military and government needs; instead of intrinsic value, usefulness of education is being considered. Kellie (2003) too showed in her 12-15 month research on two company-based management education programmes in the UK that "what constitutes relevant knowledge is no longer the exclusive domain of the educationalist. It is more closely tied to the perceptions of the organizational stakeholders.' 


\section{Critiquing technicist-managerialist thinking:}

The following paragraphs present a debate on the advantageous and disadvantageous features of the technicist-managerialist discourse in management education. Some scholars see it as a necessary feature of management education, while others think it is a short-sighted approach.

Growth in technicist-managerialist thinking and metaphors, such as students as customers and business schools as producers continues unabated, even though Grey and Mitev (1995a) remind us that the value of education cannot be determined beforehand. Payment of fee is only a condition of entry, not a guarantee of learning. Among scholars who criticize such a mode of thinking, Thomas and Anthony (1996) believe that reducing management education's educational aspect will make it more like short-term training undertaken to learn a specific technique or course. Seeing education merely as commodity ignores the character building and personality development in education, add Cope and I'Anson (2003). Moreover, as Thomas and Anthony (1996) observe, learning only for earning (utility) is short-term; it does not affect students' being and is boring and destructive to curiosity and imagination. Real management education, on the other hand, engages social, political and conceptual abilities, and not merely techniques that can be learnt on the job and that can change over time.

Among those who view the technical part in management education favourably, Burgoyne (1995) observes 'it would be morally wrong and wasteful to fumble or fail at a morally valuable performance for reasons of technical inefficiency. To fail to teach or learn or apply genuinely useful technical expertise is at least indirectly immoral' (p. 94). He sees technical competence 'as a necessary adjunct to moral development' (p. 91). Besides, King (1995:101) points out that it has never been adequately proven that a technicist-managerialist MBA is not intellectually demanding or that it refrains from illustrating detailed understandings or that a concern for quality is dictated by a 'market conception' that sees students as consumers and teachers as producers.

Taking the debate forward, Grey and Mitev (1995b: 104-5) reply to Burgoyne's (1995) and King's (1995) arguments by acknowledging that 'managers are aware both of moral issues (they are human beings!) and, often, the limits to management techniques... But the question is how management is presented and understood.' The point, according to them, is not whether management education syllabi should or should not teach techniques but whether the discipline of management is presented as a set of techniques to be mastered or an educational discipline that develops students' social and conceptual abilities. Fox (1994) and Jessop (2002) bring in another point about management education not being value-neutral. They point to the managers' role in reproducing and transforming cultures through participation in activities having extended social consequences. As such, management education should contribute to socio-economic development of a country, as against equipping students with a mere set of techniques to carve out their careers with. Such a socially responsible attitude, Jessop (2002) says, will give them not only techniques, but also values, ethical reasoning and ability to link with people. 
Though I believe that a professional degree like MBA needs to take account of market needs, it must pay significant attention to the 'nurturing side of education' - development of a sense of responsibility through inculcation of moral values. Education which fails to clarify our central convictions is mere training or indulgence (Schumacher, 1973). If education cannot teach non-material values that give meaning to life, how can it create a fair society, questions Gatto ${ }^{3}$.

\section{METHODOLOGY OF THE RESEARCH}

In order to investigate the incidence of technicist-managerialism in the values of MBA programmes, intensive research was conducted in two business schools of Pakistan. These two schools were chosen because of their leading positions in the business academia of the country. One school belonged to the private sector and the other to the public sector. Respecting their confidentiality, the two schools are represented as Leaders Academy and Pioneer Academy in this paper.

Since I wanted my respondents' uninhibited comments on the values found in their schools or in their colleagues, I conducted open-ended interviews with students, school teachers and administrative staff from these two schools. Some managers in industry were also approached to collect their comments on MBA students they employed or worked with. These interviews were either in-depth interviews with individuals, joint interviews with two participants or focus group interviews with larger groups of students. As respondents' uninhibited views on their MBA programmes and/or with MBA students were required, interviews were conducted in a way of inviting participants to freely air their views and opinions, with order of questions, length of answers, the language of the interview and other such practicalities largely at their consideration (see Gubrium and Holstein, 2003a and b; Henerson et al, 1988; Arksey and Knight, 1999). The following research questions were asked to elicit participants' views on the kinds of values endorsed in their business schools or found in the MBA graduates they worked with:

What are the main values encouraged in your business school? Or

How would you comment on the values about work MBA graduates come endowed with when they enter practical (work) life?

What kinds of careers are you (or your students) looking forward to after completing your (their) MBA degree?

How would comment on the curriculum of your business school? Please include in your answer your comments on the teaching of ethics and social responsibility in your programme.

A total of 21 respondents were interviewed from the corporate sector and 22 from the academia, of which 14 were teachers and 8 were students. In addition, three joint (two

\footnotetext{
${ }^{3}$ www.spinninglobe.net/gattopage.htm
} 
in one school and one in another) and two focus group (one of each school) interviews with also arranged with the students of these schools.

In addition to interviews, official publications and web-sites of these two business schools were also referred to shed more light on the interview comments relatively researcher-unobtrusive manner (Hodder, 1998).

Analysis of interviews was then carried out using a modification of Hycner's (1985) framework for qualitative data analysis. After developing value themes from interview quotes, relevant excerpts from school publications were added to complete the themes that are presented in the next section.

\section{TECHNICIST-MANAGERIALISM IN THE PAKISTANI MBA: RESEARCH FINDINGS}

Section 2.0 described some elements of technicist-managerialist thinking, the values emanating from such an approach towards education and the consequences ensuing from it. In this section I will take a look at the Pakistani MBA programmes to see how technicist-managerialism was visible in the values and the curricula of my chosen business schools.

Technicist-managerialist thinking in the values endorsed in the two business schools:

In the following paragraphs I present some of the values endorsed in MBA programmes I researched. I do not imply that these MBA programmes are the source of these values (although they could be) but that they are being encouraged or at least not discouraged in these programmes. Whether these values are learnt from society and/or find their way into management academe from management practice is beyond the scope of this paper. This paper only highlights those values that find support or at least no opposition in the two MBA programmes I looked into. I have presented these values as quotes (given in italics) from respondents' interviews and excerpts from the schools' publications. (Respondents' names have been altered for reasons of confidentiality). In the next section I will discuss how I see these values coming from a technicist-managerialist stance.

Hard work versus favouritism and flattery:

Hard work was listed among the core values the schools promoted (Leaders' Alumni Annual, 2003:35; Leaders' general booklet; Pioneer Program Announcement, 20045). One student, Qaiser, found hard work an essential ingredient of a successful work life

Tomorrow you go to an organization... Nobody's gonna say 'You know what, you work so hard, I'll make you manager tomorrow.' No, you have to do the work. As long as you do the work, God himself will show you the way. As long as you do the work, rewards will come. 
Many students, however, confessed of taking of 'short cuts' and currying favours in order to avoid hard work. Instead they flattered teachers in order to get their way through. One student from a Pioneer focus group remarked, "It may be a very bad value but it is working for people." Some managers in industry also commented on graduates' aversion to hard work when the latter entered practical life.

Merit and professionalism versus an all goes attitude

Pioneer had an "almost callous attitude" towards merit, Dawood from the administration reported. No kind of requests whatsoever were entertained for admitting or upgrading any unmeritorious candidate for admission. Karim from Leaders' administration also proudly asserted, "The bedrock of Leaders, how we define ourselves, is one wordmerit."

Regarding professionalism, one student from Pioneer appreciated, "By the time you graduate out of Pioneer, rough edges get smoothened, you get a professional outlook." Leaders too stressed professionalism as was seen form their publications. Nasim, from the school's faculty called ability to live and work with people from different sociocultural values and backgrounds as a "professional attitude towards life."

But managers in industry did not always see professionalism in business graduates. For example, Akram, a manager from a local bank, found the concept of quality missing at Pioneer because of rushing from one assignment to the next. He said

All goes in Pioneer. But in real life you have to finish at a 100\%. That concept of quality is lacking over there. You know, you're always running around, just want to fill in the blanks, do the papers or whatever, just to go back to the next course, to the next grade, to the next semester.

Honesty and integrity versus wrong ways

Both schools had honesty and integrity written down in their publications (Leaders' Alumni Annual, 2003:35; Leaders' general booklet; Pioneer Program Announcement, 2004-5) as one of their major work values. Nosheen from Leaders' student body confidently claimed, "Everywhere you can get away with cheating, but not at Leaders, definitely. That I can say for sure." Omar from Pioneer also proclaimed of having seen "people speak up, whistle-blowing, at least try to do what they can do" in organizations, even when they were serving only as interns.

On the other hand, "wrong” ways of achieving ends at Pioneer were also mentioned. For example, Farhat, a management trainee in a multinational and a Pioneer graduate, confessed, "It [Pioneer] taught me there's always a wrong way of getting things done, which usually works [laughs]. It's a reality in Pakistan.” As such, Pioneer students said they had learnt from their interaction at their business school not to trust one another. 
Discipline versus tolerance:

To "survive" in Pioneer students had to discipline themselves. Students, teachers and alumni of Pioneer commented on the rigorous discipline of the place, with many students and alumni listing discipline as the foremost value they had learnt from the institution and which had proven very beneficial in their professional lives. At Leaders too, students were expected not to be late in coming to class or in submitting assignments "by even a minute." Lateness was penalized by being marked absent for the session and not getting any marks for class participation in that session.

But some faculty and students did not consider Pioneer a very forgiving place. Maqsood, a faculty member, for example, expressed dismay at the school's not accommodating for genuine excuses and not forgiving students' mistakes. What worried him was the social effect of such intolerant policies. Sounding concerned, he said

Young people spend 4-5 important years of their lives with you. You tell him we can't ignore or forgive your mistakes. If he's not forgiven, how can we expect him to ignore those [meaning mistakes] of others. Society can't develop on natural path then.

Competition versus cooperation:

Monthly and yearly examinations and quizzes were much emphasized in both schools. These tests, which awarded grades from A+ to F and GPAs from 0.00 to 4.00, appeared to me to be setting students in competition with one another. Thus several students and alumni described competition at Pioneer as "cut-throat". Some teachers also acknowledged the presence of such competition in the school. Hamid (a Pioneer alumnus, a manager and a visiting faculty at Pioneer), for example, reflected

One of the problems I have with the way we are taught [at Pioneer] is that it is very centred around us. We are supposed to compete individually with others and we are supposed to beat them and win. So it's all about coming first, second and third. If you're first, the guy who is second is not first. So it's always about 'I have to beat the other guy.'

At Leaders too helping others could mean pulling oneself down in the marking of curve-based class participation. One student described her helplessness at not being able to assist a class fellow in the following words:

I could tell this person would not be able to survive. He'd lost hope. The system is very scary in this sense. Nobody can stop to help anybody else because if you help somebody else that person might cross over you and you might be the person at the bottom.

Despite competition, respondents also expressed care for their colleagues and cooperated with them in various activities. By forming learning groups of students with different talents, Leaders was endeavouring to encourage students to learn together and form bonds with class fellows. Ciran, a faculty member at Pioneer, also pointed out that 
despite being in competition, Pioneer students were "cohesive," worked in "concert" to deal with teachers, and would "take him along" who was "backward" in any way.

Networking versus trustworthiness:

As far as their interpersonal relations at work were concerned, Pioneer students underlined the importance of networking as essential to take work from others. For example, Qaiser, a third semester student, underlined the importance of networking for obtaining jobs in the following words:

Look at Harvard. It's renowned to be one of the best schools in the world. Where's the key that makes them so strong? It's the Old Boy network; it's the connections. Big companies would come to your doorstep and say, 'Hey, you did this.' Even if your GPA is not the best, they'll take you in and give you the opportunity.

Many students realized this opportunistic behaviour in their colleagues. For example, one focus group participant observed that she did not always trust friendly moves because "[they] could stab me any day in the back. They always have an ulterior motive"

Material versus personal development:

Most students saw success as something that could furnish them with a "good job" a well paying one with ample growth and learning opportunity, comfortable working environment, and little bureaucracy. Part of this success was earning an elitist status in industry by joining well-known local and multinational organizations and reaching managerial positions in a short time, which in a manager Khurram's words was such as could enable them to quickly become "a Sahib or Begum Sahibah". A Leaders' student in a focus group observed

Focus in Leaders for me is towards getting a good job. All the accounts courses we have, in the end what we are trying to do is to generate profits. One core value is that...If someone gets a very good job at Procter and Gamble, he would go for it...I mean that could be one of the goals that we have.

An MBA final year student from Pioneer, Sadaf, not only expressed her choice but also mused on where she and her fellow students could have got such ideas

This is one very good thing - this link with outside world, that we've to go to an $M N C$, get a good job... Somewhere along the line we think if we get such a GPA, we'll get such a job; if this will happen, that will follow. I don't know where we learn it from. Through teachers? Internships as well because we're getting hands on experience and practical knowledge... as well as elective courses because they've got professional teachers... Pioneer culture?

${ }^{4}$ Grade Point Average, a scale of academic performance, ranging from 0.00 to 4.00 , often used in MBA programmes. 
But Omar, another student from the same school, grieved that the narrow-minded pursuit of careers was developing a materialistic mentality in students

Pioneer in your initial semesters makes you very materialistic. For example, studies are more of a materialistic nature than [being] applicable. We lack faculty which can orient us towards that [non-materialism]. Teacher will tell you how to go out and earn salary. But in BBA 6, for the first time, I studied the Development Economics course. There I had the introduction to the idea that there is a lot more besides money in this world.

At the same time school staff, including Ciran and Moeen, regretted availability of a few personal development and extracurricular activities for students at Pioneer. Moeen regretted of students' growing interest in activities, such as picnics and movies that "don't contribute to character-building" and their declining participation in more intellectual ones, such as, debates, poetry competitions, and corporate dinners. Hamid, from industry, also criticized students' 'knowledge-for-job' approach towards education as keeping them away from obtaining the full benefit of education. He assessed the situation, "Over here knowledge is about degree, translate into job." A visiting lecturer at Pioneer, he tried to encourage his students to read more, for "At the end of the day it's the accumulation of all these ideas that will make them the type of people they want to be."

Concern for self versus concern for society:

Moeen, Sikandar and other Pioneer faculty and administrators, regarded Pioneer's students' quick employment in successful companies (local and multinational) as the school's contribution to society. Students also named a few teachers who explicitly reminded them of their social responsibilities but informed me that the subject was not really stressed upon. For example, a student Sadaf said

SI [Statistical Inference] teacher Nadeem used to talk about giving back to community. Lots of people [meaning teachers] do, for example, Entrepreneurship guest speaker, but not much emphasis on this. 'Grab a good job' - I think that's the emphasis in Pioneer.

Ciran from Pioneer faculty testified to Sadaf's remark above. Sounding upset, she said

We really teach students to be selfish - get a good GPA, go to an MNC, improve quality of your life; go abroad. Do everything for yourself; don't do anything for anyone else. Emphasis is always on yourself; emphasis is never on society, on people around you. I mean it's ridiculous. The philosophy of Pioneer, as I see, is always profit-making, always profit-making. But profit can be in spiritual terms also. But we never bother about spiritual terms.

Leaders' publications also recounted entrepreneurial achievements of their graduates as their school's contribution to society but a focus group participant observed in a frustrated tone 
Leaders as an educational institute is failing in its non-technical aspect. It's producing excellent computer scientists, excellent managers, we're producing excellent technicians but they don't have social thought as part of their education.

Other students and teachers also felt their schools had not done enough to make students realize the importance of reaching out to the larger society, nor played their own social role effectively as most of their graduates aspired to foreign multinationals.

Concern for profits versus concern for ethical behaviour:

Regarding the proposition of upholding ethical values, students talked about it alongside corporate profits or considered it workable only if it could help them obtain " a good job." A focus group student remarked that they were often told to work ethically for "there's even positive NPV $V^{5}$ attached to ethical behaviour." Though some other students informed that they were thinking of making careers in Islamic banks or where they would not have to compromise Islamic principles, participants from this focus group expressed doubt as to their upholding ethical values above everything else in their practical lives. A student in a Leaders' focus group explicated the difficulty of identifying with ethical debates

The fact is that in our culture, our society, profit making is the first and foremost objective of any organization. Values would come perhaps very low on the list... In some cases [meaning case studies] this value issue comes up. I don't think students can really associate themselves with what the discussion at that point in time is leading to.

Technicist-managerialist thinking in the pedagogy of the business schools:

Technicist-managerialism in MBA curricula becomes more evident when we take a close look at the pedagogy of the two schools. Pioneer's Program Announcement (2004-5:7) read:

The faculty ensures that the system of education at the Pioneer is a unique blend of the best in classroom instruction, case studies, role-playing, business games, class presentations, research and practical training in business organization.

Some students spoke of class presentations, out-of-class assignments, report writing and internships allowing them to be creative and building their self-confidence. Others, on the other hand, pointed to one-way lecturing, learning by rote, following a few prescribed text books, and obtaining no additional marks for creativity as constraining their freedom of expression. A student Qaiser related a teachers' behaviour in class on an occasion when he pointed out her mistake to her

\footnotetext{
${ }^{5}$ Net Present Value: A concept in finance, according to which the feasibility of a project is evaluated on the basis of net profits, in terms of value of money today, it would yield over its life.
} 
Miss, I think, there's a mistake. We looked in the book and it's not the right answer [students pointed out]. [In return the teacher replied], 'Don't tell me how to teach.' The thing is we give an answer that is right and her answer is different, we get marked down.

Ciran, a faculty member of Pioneer, also denied encouraging students to think critically. She said, "We keep talking at them. There's no dialogue... Zero or negative critical thinking." To illustrate, she explained how American textbooks and models, that might not be fully workable in Pakistan, were rarely being taught with a critical viewpoint. Rather, they were taught as "perfect models...challenging Brother Kotler [an internationally renowned American marketing professor][is] just not an option."

As far as non-technical courses were concerned, both schools had some ethically and socially oriented courses to promote ethical behaviour in business. Pioneer had courses, such as 'Business and Society,' 'Business Ethics,' and 'Audit, Ethics and IS Issues' which were taught to some MBA programmes as compulsory credit courses, to some as non-credit or elective courses and to others not at all. Other courses, such as Advanced Financial Accounting and International Marketing, also talked about social and ethical concerns, for example, about accounting for non-profit organizations. However, prescribed texts for such courses were usually foreign, as I learnt through my interviews, supplemented with articles and news from Pakistan. Other courses, such as 'Philosophy of Islam' and 'Islamic Finance' were Islamically oriented courses. Nevertheless, students claimed that Pioneer's teachers payed only "a passing reference" to the topic of ethics. For example, Omar observed

Usually the discussion is very general. They don't show you any specific direction. You should have integrity. How? No one emphasizes that.

'Islamic Ethics' (IE) was also taught as a compulsory course to second year MBA students at Leaders and ethical issues were dealt with in several business courses as part of management problems. But according to the course teacher, and as students themselves confessed, not many students succeeded in understanding the relevance of the course to their prospective careers. The course teacher, Kabir, complained that students professed "they already know Islam" and seemed to regard the course as "irrelevant to modern, practical requirements of the society at large." A focus group participant said

Focus in Leaders for me is towards getting a good job. All the accounts courses we have, in the end what we are trying to do is to generate profits... But at the same time we have courses like Islamic Ethics, etc. So for me there's a big contradiction. I personally feel that our focus should be just on profit-making because that is what our real intention is. And those courses are just on the sidelines. 
Technicist-managerialist thinking in catering to the market:

Pioneer staff often mentioned the need to cater to the requirements of the industry by sometimes referring to their students as "products" and the corporate sector as their “market.” Dawood, from Pioneer faculty and administration, stated

We are looking to sell Pioneer to potential talented students and their families... And on the other hand we have a market which is out there, where our graduates will go and find jobs, and we must therefore pay attention to what that market is looking for.

Another administrator from the same school believed in keeping the customer in focus if "you're preparing a product for the market."

Business education is a job-oriented degree; the objective is to train people. Basically you're preparing a product for the market. It's not that what values you are giving them but seeing that your product should be acceptable in the market. Values and philosophies, these are jargons, I am sorry to say. I don't think anyone seriously believes in it.

Consequences of technicist-managerialist thinking:

In their zeal for competition and hard targets, students were criticized in industry for not being well trained in dealing with people and working in teams. Many managers also implied that they found MBAs graduates' frequent and unplanned job-switching irresponsible and disloyal on their part and even dishonest, especially when they had shown keen interest in the jobs in their interviews a little while before quitting. Moreover, it was threatening to students' own careers.

Looking forward to glamorous careers and being in a hurry to move up, fresh graduates, in managers' and teachers' words, often faced adjustment problems. Not prepared for modest jobs, they encountered problems when they had to carry out menial work, such as filing, stamping, and sitting on the ground with rolled up sleeves with agricultural clients. They were also considered to be outspoken by their colleagues. Explaining the initial entrance period of business graduates, Mariam from a local chemicals company, related

When they came in the job market they realized that if you're working in Shell, you'll have to be there at the port. Roll up your sleeves and be there where the truckers are. You'll have to sit with them on the ground, soil your clothes because they're your customers. And they were not ready to do that.

Ikraam, a senior manager at a local pharmaceutical company also observed about Pioneer's students that

As far as practical application is concerned, usually for the first 2-3 years you find yourself totally disoriented and out of place. 
Material and elitist concerns also created problems of balance in practical work life. Hamid, an alumnus of Pioneer and a manager at a famous multinational, noted

Balance is very important in one person's life. I guess initially we are so zesty about lots of things that we lose our balance - of personal life, our family and our commitment to others.

Consequently, not many respondents agreed to their business schools' building of leadership skills in their students, though several teachers and alumni argued to the contrary. Nasim, from Leaders' faculty, who himself taught the subject Leadership, said

We are producing more like managers - very good in analytical skills and good communication skills, they lack really leadership qualities. Even though I teach leadership, I'm not very confident if we're doing a good job.

\section{DISCUSSION}

The findings presented above show that both kinds of commendable and contemptible values were being endorsed in the two business schools. Students were using values that were helping them achieve results, be they hard work and professionalism or dishonesty and flattery; institutes too enforced discipline but became intolerant at times. Students tried every possible measure to obtain jobs but quit them on finding better ones. This shows that in these schools management was regarded as a set of morally and politically neutral techniques, committed to the idea of instrumental rationality (see section 2.0 for explanation).

Management scholars, such as Bell (1979) and Boje (1996) and Burgess (1996) have questioned even the so-called commendable values that were encouraged in business schools. Bell (1979), for example, believes that too much emphasis on meritocracy, without concern for the less privileged, can tantamount to technicism. Boje (1996), in a postcolonial vein, considers regimental discipline as the gaze of teachers over students. Burgess (1996) is of the opinion that the kind of self-sovereignty encouraged in capitalistic institutions encourages to irresponsible behaviour. Commenting on some of the ills of pursuing careers blindly, Peltonen (2000:412) remarks

Career teaches ruthlessness by neglecting the personal responsibility for consequences of behaviour and highlights instead norms as mere regulative rules of the game.

The concept of competition, especially unhealthy competition, is criticized by scholars for resulting in not only individualistic thinking but also for weakening the degree to which students can serve as others' learning resource. Directed inwards, rather than outwards, exams and grades that several of my respondents talked about, reinforce conformity, yet lead to individualized mentality (also see Leavitt, 2001; Lataif et al, 1992). On a larger scale, if not followed by innovation, competition can lead to problems of instability, inconfidence and less trust in the economic system (O'Hara, 2004). 
In their zeal for competition, MBA graduates' lacked the "take along concept," according to some managers. Hence, they also did not consider them effective team players. Critics, such as Vince (1996) and Currie and Knights (2000), hold the excessive training in objective issues, such as competitiveness, aggression, and lack of emotions, that technicist-managerialist management education imparts and that prototype management leaders are supposed to be endowed with, responsible for this ineffectiveness. Gatto ${ }^{6}$ criticizes networks that many MBA students thought essential for career advancement. According to him they give temporary solutions and require only part of the person, not the whole. Though they may get some work done, they do not nourish members emotionally, which is necessary for teamwork, cooperation and coordination of human effort (Sanchez and Levine, 1999). This is encouraged in management education, as Marxists and postcolonialists say, by highlighting class differences and not giving equal weight to managers and workers. The emphasis is always on management, though the theory promotes the idea of organizational members (Leavitt, 2001).

Seeing the varying conceptions of and limited commitment to social responsibility among my research participants, I am reminded of a study of MBA students by Dolan (1997), who found that MBA graduates could not agree on the definition of social responsibility. For them, it ranged from giving charity, to volunteer work, to not working for a tobacco company. Such vague and disparate understanding of social responsibility, I believe, comes from the inadequate importance this topic is granted in technically managerialist management curricula. Scholars, including Epstein (1999) and Verschoor (2003) also feel management education does not concern itself adequately with notions of social responsibility.

Teaching curricula and methods too spoke of a technicist-managerialist ideology. Many students complained of not having enough opportunity to reflect and not being allowed to think freely. Non-technical subjects too were a "challenge" for both teachers and students because students either considered such subjects "irrelevant" to their careers ahead or did not identify with the discussions in class. According to Sherman (2003), this is so because concepts of personal growth, intellectual development, scholarly community, improving society and liberal education are absent from 'fads' that form a popular part of technicist-managerialist MBA education. Besides, as many students said, generally no more than "a passing reference" was given to ethical and religious topics, compared to the main management concepts in the curricula. Some teachers too informed that courses such as Islamic Ethics were taught primarily as administrative requirements and spoke of the lack of material on the topic. This is why they had to resort to American books for teaching (Islamic) ethics. However, they added local illustrations and examples to the texts they used. Nevertheless, I saw an interest in both schools in opting for careers in Islamic banking, alongside those in multinational companies and banks. These views remind me of Baetz and Sharp's (1999) and McDonald's (2004) findings in section 2.0 as to why human and ethical issues are not given due importance in management curricula: ethics are seen as

${ }^{6}$ www.spinninglobe.net/gattopage.htm 
irrelevant and hard to understand and difficult to translate into practical work life. When ethics are finally mentioned, they are often so alongside material benefits, such as a "positive $N P V^{7}$ " or a "good job." Roberts (1996) sees such evaluative justification of ethics in terms of opportunities and threats as 'triggered by greed'.

In section 4.0 I discussed how the business schools were paying heed to the market in formulating their curricula, in fact so much so as to compromise the value-giving element in them. Such a concept of education as a commodity for sale to the market ignores the nurturing or character-building side of education, say Cope and I'Anson (2003). The use of metaphors, such as quality assurance, benchmarks, exporting education and the like is also at odds with the Islamic concept of education. According to Bilal Philips ${ }^{8}$, a contemporary Islamic scholar of renown, Islam regards education as worship, a process of advancement in both this life and the next. Other religious models, including the Vedic, also consider education as worship. Chinese see teachers as 'kings,' in the words of a Chinese colleague. Such models place the teacher on a level above the student. They expect the teacher to share his/her knowledge and experience with the student in return for reverence and obedience. The idea of a material exchange is absent in classical religious texts. But when education is considered a commodity, material exchange becomes important (Business 2.0, 2005; Pring, 1998) and education becomes training (Thomas and Anthony, 1996) provided for a fee.

Such technicist-managerialist mentality trickles down into management practice, says Park (1998), where a manager is supposed to respond 'objectively, professionally, and dispassionately' to 'objective' factors. He must work as a technician. Poole (1996) considers this an issue of opposing constructs. As familial and emotional relationships are deemed 'irrational' in capitalistic and bureaucratic means of production, they are separated from work or public life. Within the public sphere human beings are valued so far as they serve as means towards distinct goals. Thus technicist-managerialist thinking divides management into masculine and feminine, public and private, work and non-work, and religion and non-religion.

\section{CONCLUSION}

After reviewing the various values endorsed in the two business schools, it can be said that technicist-managerialism indeed influenced the thinking in these institutions. Students and staff displayed a commitment to instrumental rationality by using whatever values benefited them in pursuit of their careers. Teaching curricula and methodology too betrayed a technicist-managerialist stance. Consequently students were seen lacking in people management skills and not highly committed to ethical and/or social responsibility, thus raising the question whether the two leading business schools were really preparing business leaders of future.

${ }^{7}$ Net Present Value: A concept in finance, according to which the feasibility of a project is evaluated on the basis of net profits, in terms of value of money today, it would yield over its life.

${ }^{8}$ www.bilalphilips.com/abouthim/artic01e.htm 


\section{REFERENCES}

Alvesson, M., and Willmott, H. (1996). 'Making Sense of Management: A Critical Introduction', London: Thousand Oaks, California: Sage.

Arksey, H., and Knight, P. (1999). 'Interviewing for Social Scientists: An Introductory Resource with Examples’, London: Sage.

Auken, S.V., Wells, L.G., and Chrysler, E. (2005). 'The Relative Value of Skills, Knowledge and Teaching Methods in Explaining Master of Business Administration (MBA) Program Return on Investment', Journal of Education for Business, 81(1), Washington, D.C.: HELDREF, pp. 41-45.

Baetz, M.C., and Sharp, D.J. (2004). 'Integrating Ethics into the Core Business Curriculum: Do Core Teaching Materials do the Job', Journal of Business Ethics, 50(1), Dordrecht, Holland; Boston: D. Reidel, pp. 53-62.

Bell, D. (1979). The Cultural Contradictions of Capitalism, London: Heinemann.

Birnbaum, R. (2000). Management Fads in Higher Education, Where They Come From, What They Do, Why They Fail, San Francisco: Jossey-Bass.

Boje, D. (1996). 'Management Education as a Panoptic Cage' in French, R., and Grey, C. (eds), Rethinking Management Education, California: Sage, pp. 172-95.

Boyatzis, R.E., Cowen, S.S., Kolb, D.A., and associates (1995). 'Innovation in Professional Education - Steps on a Journey From Teaching to Learning', San Francisco: Jossey-Bass.

Burgess, Y., (1996). 'The Myth of Progress', Glasgow: Wild Goose.

Burgoyne, J.G. (1995). 'The Case for an Optimistic, Constructivist and Applied Approach to Management Education: A Response to Grey and Mitev', Management Learning, 26(1), London: Sage, pp. 91-96.

Burke, L.A., and More, T.E. (2003). 'A Perennial Dilemma in OB Education: Engaging the Traditional Student', Academy of Management Learning and Education, 2(1).

Business 2.0 (2005). 'The ROI on Your MBA: We Survey the Country's Top Business Schools to Tell You How Good an Investment They Really Are', 6(8), San Francisco, pp. 99.

Cavanaugh, J.M., and Prasad, A. (1996). 'Critical Theory and Management Education: Some Strategies for the Critical Classroom' in French, R., and Grey, C. (eds.), Rethinking Management Education, California: Sage, pp. 76-93. 
Clegg, S.R., and Ross-Smith, A. (2003). 'Revising the Boundaries: Management Education and Learning in a Postpositivist World', Academy of Management Learning and Education, 2(1).

Cope, P., and I'Anason (2003). 'Forms of Exchange: Education, Economics and the Neglect of Social Contingency', British Journal of Educational Studies, 51(3), pp. 219-32.

Currie, G., and Knights, D. (2000). 'Towards a Critical Pedagogy in MBA Education', paper presented at the second Connecting Learning and Critique Conference, Lancaster University, pp. 87-105.

Currie, G., and Knights, D. (2003). 'Reflecting on a Critical Pedagogy in MBA Education', Management Learning, 34(1), pp. $27-49$.

Dolan, K.A. (1997). ‘Kinder, Gentler M.B.As’, Forbes, 159(11), pp. 39-40.

Ehrensal, K.N. (2002). 'Making Managers: Towards an Understanding of How Textbooks, Lectures and Management Case Studies Interact to Inculcate Linguistic and Managerial Habitus in Undergraduate Business Students', Conference Paper presented at Cambridge University, pp. 137-45.

Epstein, E.M. (1999). 'The Continuing Quest for Accountable, Ethical, and Humane Corporate Capitalism', Business and Society, 38(3), pp. 253-67.

Fineman, S., and Gabriel, Y. (1994). 'Paradigms of Organizations: An Exploration in Textbook Rhetorics', Organization, 1(2), London: Sage, pp. 375-99.

Fox, S. (1994). 'Debating Management Learning: II', Management Learning, Sage Pub., London, 25(4), 579-97.

Fox, S. (2001). 'Research Methods Module Handouts and Lecture Notes', MA in Human Resource Development and Management Learning, Lancaster University Management School.

Friga, P.N., Beths, R.A., and Sullivan, R.S. (2003). 'Changes in Graduate Management Education and New Business School Strategies for the Twenty First Century', American Management Learning and Education, 2(3).

Gatto, J.T. 'We Need Less School, Not More - Families, Communities, Networks and the Proposed Enlargement of Schooling', Source: www.spinninglobe.net/gattopage.htm Last accessed on March 13, 2006.

Gosling, J., and Mintzberg, H. (2004). 'The Education of Practicing Managers', MIT Sloan Management Review, 45(4), Cambridge, pp. 19-22. 
Grey, C., and Mitev, N. (1995a). 'Management Education: A Polemic', Management Learning, 26(1), London: Sage, pp. 73-90.

Grey, C., and Mitev, N. (1995b). 'Neutrality, Critique and Quality: A Reply to Burgoyne, McAulay and King', Management Learning, 26(1), London: Sage, pp. 103-07.

Grey, C., Knights, D., and Willmott, H. (1996). 'Is Critical Pedagogy of Management Possible?' in French, R. and Grey, C. (eds.), Rethinking Management Education, California: Sage, pp. 94-110.

Gubrium, J.F., and Holstein, J.A. (2003a). 'From the Individual Interview to the Interview Society' in Gubrium, J.F. and Holstein, J.A. (eds.), Postmodern Interviewing, Thousand Oaks: Sage, pp. 21-49.

Gubrium, J.F., and Holstein, J.A. (2003b). 'Active Interviewing' in Gubrium, J.F., and Holstein, J.A. (eds.), Postmodern Interviewing, Thousand Oaks: Sage, pp. 67-80.

Henerson, M.E., Morris, L.L., and Fitz-Gibbon, G.T. (1988). 'How to Measure Attitudes', California: Sage.

Hodder, I. (1998). 'The Interpretation of Documents and Material Culture' in Denzin, N.K., and Lincoln, Y.S. (eds.), Collecting and Interpreting Qualitative Materials, Thousand Oaks, California: Sage.

Huczynski, A.A. (1993). 'Explaining the Succession of Management Fads', The International Journal of Human Resource Management, 4(2), pp. 443-63.

Hycner, R. (1985). 'Some Guidelines for the Phenomenological Analysis of Interview Data', Human Studies 8, Netherlands.

Jessop, B. (2002). 'The Future of the Capitalist State', Oxford: Polity Press.

Kallinikos, J. (1996). 'Mapping the Intellectual Terrain of Management Education' in French, R. and Grey, C. (eds.), Rethinking Management Education, California: Sage, pp. 36-53.

Kellie, J. (2003). 'Management Education and Management Development - Widening Participation or Narrowing Agenda', paper presented at the Third Critical Management Studies Conference, Lancaster University, July 2003.

King, M. (1995). 'Quality and Management Education: A Response to Grey and Mitev’, Management Learning, 26(1), London: Sage, pp. 101-02.

Lataif, L.E., Mintzberg, H., Leonard, E.W., Saka, B., Steele, L., Haruyama, A., Mitroff, I., Hendry, J., Wiseman, C., White, J., Sokolow, D., and Miller, H. (1992). 'MBA: Is the Traditional Model Doomed?' Harvard Business Review, 70(6). 
Leavitt, H.J. (2001). 'Socializing Our MBAs: Total Immersion? Managed cultures? Brainwashing?’ California Management Review, pp. 127-43.

McDonald, G.M. (2004). 'A Case Example: Integrating Ethics into the Academic Business Curriculum', Journal of Business Ethics, 54, Dordrecht, Holland; Boston: D. Reidel, pp. 371-84.

Mitroff, I.I., and Denton, E.A. (1999). ‘A Spiritual Audit of Corporate America', San Francisco: Jossey-Bass.

O'Hara, P.A. (2004). 'Cultural Contradictions of Global Capitalism', Journal of Economic Issues, Lincoln, 38(2), pp. 413.

Park, H. (1998). 'Can Business Ethic Be Taught? A New Model of Business Ethics Education', Journal of Business Ethics, 17(9/10), Dordrecht, Holland; Boston: D. Reidel.

Peltonen, T. (2000). 'Elite Because Alert? Ethics, Identity and Managerial Career', Second Connecting Learning and Critique Conference, Lancaster University, pp. 403-18.

Poole, R. (1996). Morality and Modernity, London: Routledge.

Pring, R. (1998). 'Liberal Versus Functional Values in Higher Education' in Talati, J.J., Vellani, C.W., Herberg, P., Sutton, R.A.L., Qureshi, A.F., Pardhan, S. and Bacchus, K. (eds.) Higher Education: A Pathway to Development, Karachi: The Aga Khan and Oxford University Press.

Roberts, J. (1996). 'Management Education and the Limits of Technical Rationality: The Conditions and Consequences of Management Practice' in French, R. and Grey, C. (eds.), Rethinking Management Education, California: Sage, pp. 54-75.

Roy, A.K., and Roy, L.C. (2004). 'The Importance of Teaching Ethics', Business and Economic Review, 50(2) Columbia, pp. 22.

Rynes, S.L. Trank, C.Q., Lawson, A.M., and Ilies, R. (2003). 'Behavioral Coursework in Business Education: Growing Evidence of a Legitimacy Crisis', Academy of Management Learning and Education, 2(3), pp. 269-83.

Sanchez, J., and Levine, E., 'Is Job-Analysis Dead, Misunderstood or Both?' in Kraut, A. I., and Korman, A.K. (eds.) (1999) Evolving Practice in HRM: Responses to a Challenging World of Work, San Francisco: Jossey-Bass.

Schumacher, E.F. (1973). Small is Beautiful - Economics as if People Mattered, New York: Harper and Row. 
Sherman, H. (2003). A review of 'Management Fads in Higher Education: Where they Come From, What They Do, Why They Fail', Academy of Management Learning and Education, 2(3).

Spivak, G.C. (1993). 'Outside in the Teaching Machine', London: Routledge.

Thomas, A.B., and Anthony, P.D. (1996). 'Can Management Education Be Educational?' in French, R., and Grey, C. (eds.), Rethinking Management Education, California: Sage, pp. 17-35.

Verschoor, C.C. (2003). 'Is Ethics Education of Future Business Leaders Adequate?' Strategic Finance, 85(2), Montvale, pp. 20.

Vince, R. (1996). 'Experiential Management Education as the Practice of Change', in French, R., and Grey, C. (eds.), Rethinking Management Education, California: Sage, pp. 111-31.

Zych, J.M. (1999). 'Integrating Ethics Issues With Managerial Decision-Making in the Classroom: Product Support Program Decision', Journal of Business Ethics, 18(3), Dordrecht, Holland; Boston: D. Reidel, pp. 255.

Websites

www.bilalphilips.com/abouthim/artic01e.htm

Leaders' Academy official website

Pioneer's Academy official website

Higher Education Commission of Pakistan website. www.hec.gov.pk

School Publications

Leaders MBA Pamphlet

Leaders Case Research Centre (CRC) pamphlet

Leaders General Pamphlet

Leaders General Booklet

Leaders National Outreach Programme (NOP)

Leaders Alumni Annual 2003

Pioneer Program Announcement, 2004-5

Leaders Student Handbook, 2004-5

Enduring great companies preserve their core values and purpose while their business strategies and operating practices endlessly adapt to a changing world. This is the magical combination of "preserve the core and stimulate progress". Jim Collins 